\title{
The first green lacewings from the late Eocene Baltic amber
}

Vladimir N. Makarkin, Sonja Wedmann, and Thomas Weiterschan

Acta Palaeontologica Polonica 63 (3), 2018: 527-537 doi:https://doi.org/10.4202/app.00504.2018

Pseudosencera baltica gen. et sp. nov. of Chrysopinae (Chrysopidae, Neuroptera) is described from Baltic amber. Additionally, another species, Nothochrysa? sp.

(Nothochrysinae), is left in the open nomenclature. Pseudosencera baltica gen. et sp. nov. represents the oldest confident record of Chrysopinae. The new genus lacks the apparent forewing intramedian cell, and possesses three character states not found in other Chrysopinae: the simple AA1, the short basal crossvein between $\mathrm{M}$ and $\mathrm{Cu}$, and 5-6 rings of setae on the antennal flagellomeres. This genus is probably a specialised form in a basal branch of Chrysopinae, that could not be attributed to any of the known tribes. The specimen of Nothochrysa? sp. consists only of fragments of the forewings. The late Eocene Baltic amber represents the oldest horizon where Chrysopinae and Nothochrysinae are found to coexist. It is highly likely that Chrysopidae were extremely rare in these forests.

Key words: Neuroptera, Chrysopinae, Nothochrysinae, Cenozoic, Baltic amber.

Vladimir N. Makarkin [vnmakarkin@mail.ru], Federal Scientific Center of the East Asia Terrestrial Biodiversity, Far Eastern Branch of the Russian Academy of Sciences, Vladivostok 690022, Russia. Sonja Wedmann [Sonja.Wedmann@senckenberg.de], Senckenberg Forschungsstation Grube Messel, Markstrasse 35, D-64409 Messel, Germany. Thomas Weiterschan [thomas.weiterschan@web.de], Forsteler Strasse 1, 64739 Höchst Odw., Germany.

This is an open-access article distributed under the terms of the Creative Commons Attribution License (for details please see creativecommons.org), which permits unrestricted use, distribution, and reproduction in any medium, provided the original author and source are credited. 
Fof Full text $(1,007.3 \mathrm{kB})$ 